\title{
Memoirs of the Battle of Okinawa: From the Perspective of 'Mabuigumi'
}

\author{
Junghee Kim \\ Division of Global Language and Literature College of Humanities, Kyonggi University, South Korea \\ rusia73@hanmail.net
}

\begin{abstract}
This article focuses on the story 'Mabuigumi' ('Spirit Stuffing,' 1998) by Medoruma Shun, a contemporary writer of Okinawan descent. The story explicitly depicts the history of the Battle of Okinawa and the people who were traumatized by the war. First, this article demonstrates that landscapes and living things evoke memories of the war and people, and they play a significant role in showing that people's present lives remain threatened. Second, the article conjectures that an āman (a hermit crab) represents Okinawa, which was traumatized by the mainland, and shows that Uta (the protagonist) is burdened by the guilt of her own survival. In addition, it considers the love of a mother (Omito) and son (Kōtarō) for each other. Third, this article illustrates that the history of the mainland was decentralized through visual expressions of personal memories of war. The history of mainland Japan does not regard the fact that Japanese soldiers killed Okinawans during the Battle of Okinawa. History, as officially narrated by the Okinawans, changes its narrative content depending on the shifting relationship between Okinawa and the mainland. This work relativizes and decentralizes the official historical narratives of the mainland and Okinawa through repressed personal memories of the war.
\end{abstract}

\section{Keywords}

landscape and living things, metaphor, Battle of Okinawa, memory, decentering

\section{Introduction}

The island of Okinawa has a unique history in Japan due to geopolitical sensitivity. It is located on the southwestern tip of the Japanese archipelago, between the East China Sea and the Pacific Ocean, and its strategic geographical location has shaped its history. In 1872, the Meiji government annexed Okinawa, which was part of the Ryūkyū Kingdom, and 
made it an integral part of Japan. Thus, the Okinawa Prefecture was established. The Battle of Okinawa started in 1945 and was one of the ground battles fought in Japan during World War II (hereafter referred to as WWII). Indeed, during the Battle of Okinawa, the island was sacrificed as a barrier to protect the Japanese mainland from foreign forces.

After Japan was defeated in WWII, Okinawa was governed by the United States military in the postwar period until it was returned to Japan in 1972. During the Cold War (a period of geopolitical tension between the US and the former Soviet Union and respective allies), Okinawa was considered a strategic location for maintaining peace in the East Asian region, and the construction of a US military base was encouraged, as its presence was deemed critical to Japan's security. Medoruma Shun (1960-present), a contemporary Okinawan writer, uses the traumatic history of Okinawa as the background for his novels. His works are rooted in Okinawa's rich natural environment and unique customs.

The short story 'Mabuigumi' ('Spirit Stuffing,' 1998) depicts a woman who is carrying with her the trauma of the Battle of Okinawa. This work was published in the novel Tripper in 1998 and was later included in a collection of short stories of the same name, Mabuigumi (1999). The fictional story 'Mabuigumi' narrates a strange incident from a small village located on an Okinawan beach. Mabuigumi is one of the folk rituals performed in the Okinawa, Amami, Miyako, and Yaeyama archipelagos, and is a term coined by merging the words mabui and gumi, which mean "spirit" and "to put into," respectively. The folk ritual is practiced to reinstate a missing spirit back into the body after experiencing an accident. Kōtarō, a man in his 50s, loses his spirit (mabui) on the beach, and an āman (a hermit crab) enters his mouth while he lies unconscious. Uta, the village shaman (priestess) who always treated Kōtarō affectionately, as if he were her own son, speaks to Kōtarō's willful spirit to summon it back into his body. However, Kōtarō's soul cannot be returned to his body. As the days pass, no one can figure out how to safely remove the āman, let alone understand why it entered Kōtarō's body, until the village priestess encounters a spawning sea turtle on the beach. This image triggers an epiphany and evokes buried memories of the Battle of Okinawa, which took place over fifty years earlier.

Finally, Kōtarō is killed by the āman, which is then killed by Uta and the other villagers. Kōtarō's spirit then rises above the sea; Uta prays with her hands folded, but her prayers go unanswered.

This article considers the following. First, it examines how the landscape and living things of Okinawa evoke in Uta's mind memories from the Battle of Okinawa. Second, it discusses the various meanings of the āman as depicted in the story. Third, it attempts to decentralize the institutionalized historical discourses on Japan's mainland and Okinawa by illustrating individual war experiences.

\section{Memories and Circuits of the Past}

Okinawa's landscape and living things evoke poignant memories of the war witnessed by the characters, and the pasts of those affected by the violence play a key role in shaping the present. The story begins with an āman entering Kōtarō's mouth, and Kōtarō's wife, Fumi, informing Uta of this event. Kōtarō, who went to the beach the previous night to drink and sing songs while playing the sanshin (a stringed instrument used in Okinawa and the Amami Islands in Japan), fell into a deep sleep during which the āman entered his mouth. Fumi finds him the next morning. Uta thinks that Kōtarō's spirit had left his body and could not protect him, which allowed the āman to enter his mouth. Uta, a female shaman (yuta) with the ability to recall spirits, begins the ritual (mabuigumi), which has long been passed down in the village, to bring back Kōtarō's spirit. However, even after five days of performing this ritual, Uta's efforts to return Kōtarō's mabui to his body are unsuccessful. The āman seems to be absorbing the nutrients from Kōtarō's body, and Kōtarō begins to look 
emaciated. On the sixth day, Uta returns to the beach where Kōtarō's spirit sits, and, together, they gaze out at the sea. Uta, who falls asleep on the beach, awakens to find Kōtarō standing about five meters away. At his feet, she observes a sea turtle digging a hole to spawn.

As it dug its hole, the turtle breathed hoarsely, lifting its head every so often. With a solemn expression, Kōtarō watched. "So this is what you were waiting for." The instant she uttered these words, Uta realized this was the exact spot where she had seen a sea turtle laying its eggs on the night Omito died. She sat down on her heels, turned toward the turtle, and brought her hands together in prayer. (Medoruma, 2011:126)

Seeing the sea turtle preparing to spawn, Uta is reminded of the Battle of Okinawa. Strangely, the death of Omito, Kōtarō's mother, is also related to the sea turtle. A US air raid had burned their village down, and the villagers had fled to the caves (gama) for safety. One night, Uta and Omito left the safety of the caves to hunt for food. Hiding in the pandanus bushes, they found a sea turtle spawning under the bright moon, in spite of the ongoing war. It seemed to Uta that the sea turtle did not belong to this world. After spawning, it walked toward the sea. Spying the sea turtle's eggs, Omito jumped out of the bushes to gather the eggs for food, but she was hit by a single rifle shot from a patrolling Japanese soldier. Uta, who watched this tragedy unfold while hiding in the bushes, was paralyzed by fear. She had witnessed a sea turtle enter the ocean that tragic night in 1945, and again sees a sea turtle when she follows Kōtarō's spirit to the shoreline, where it sits gazing at the vast beyond. The same sight of a spawning sea turtle evokes war memories more than fifty years old. Nature, which forms the basis of village life, is a medium that reminds people of the past.

Uta had the impression that the evening moonlight had not changed for decades or even centuries. She felt that the sea turtle, the one that had just dug its hole and was now returning to the ocean, was either the same one that she had seen during the war or one born from that turtle's eggs. The turtle glided into the ocean, and the waves washed away the sand from its shell. Then, it bent its neck to look back at the shore. Kōtarō turned toward the ocean and started walking slowly.

"Don't go! Kōtarō, you must not go!" Uta shouted. He paused for a moment and looked at her, then looked back toward the sea turtle, afloat in the ocean, and its head bobbing up and down on the rolling waves. As Kōtarō again began walking toward the sea, Uta suddenly felt that this sea turtle was the reincarnation of Omito.

\section{"Hey, Kōtarō! Wait! Wait!"}

She tried to grab Kōtarō from behind, but his form suddenly flickered and faded, disappearing as if it had been sucked down into the sand. Falling to her hands and knees, Uta ran her hand in circles through the sand, where Kōtaro had vanished. Two sea fireflies attached themselves to the turtle and glowed in the sand. Seized by a premonition, Uta rose to her feet and ran to Fumi's house. (Medoruma, 2011:129)

Seeing the sea turtle spawning under the bright moonlight, Uta convinces herself that it must be Omito reincarnated. She is convinced that Kōtarō's spirit will not return to his body because he is waiting for his mother, who has taken the form of a sea turtle. This is Uta's perception, which stems from her interpretation of her traumatic war memories. The protagonist's thoughts are projected by the flood of recollections that go back and forth between the past and the present (Ikeda, 2012:47-49). ${ }^{1}$ 
Uta realizes that as long as the āman remains in Kōtarō's body, it will make him so feeble that his spirit will not be able to return. The āman's attack seems to have destroyed Kōtarō, his family, and Uta's life. At this point, Uta's memories of war, which were dormant for years, resurfaced. Uta's recollection, thus, creates a parallel between the violence perpetrated by the āman and the war that killed the inhabitants of Okinawa in the past. In other words, the āman's transgression into people's daily lives is considered a metaphor for the Battle of Okinawa. This landscape, along with the aggression of the āman (Kojima, 2009:94), ${ }^{2}$ plays a critical role in bringing back significant war experiences and memories of the past, when people were either destroyed by violence or lived through it.

\section{Meaning of the Aman}

This section explores the various connotations of the āman, the hermit crab lodged in Kōtarō's mouth. Uta's mabuigumi ritual is ineffective, and she becomes completely powerless. Ultimately, all her attempts to save Kōtarō are futile. Kōtarō's spirit, which was sitting on the beach, walks toward the sea, and Uta runs to Kōtarō's house with an ominous premonition that he may die. Two photographers, one from the mainland and the other from Naha (the capital city of Okinawa Prefecture), witness Kōtarō's condition and try to photograph him. Startled by the sudden flash of the cameras, the āman withdraws from Kōtarō's mouth and lodges itself in his throat, suffocating him. Upon witnessing Kōtarō's suffocation, the bystanders become preoccupied with removing the āman from his mouth.

"Whoa!" gasped an impressed Genpachi, who was behind the door, watching through a crack. The āman had skillfully blocked the first blow of the shovel with its two pincers. However, Uta did not let her chance slip away. The blade of the hoe came whizzing down again, striking the āman's soft, ham-sized abdomen. With a dull squish, liquid squirted out in all directions, and the smell of fish filled the air. The āman's abdomen split into two. However, the creature did not release its hold on the shovel. Uta swung the hoe again, striking the āman's joints and severing the pincers that held the shovel. As the pincers snapped off, Kinjō tumbled over. With its remaining legs, the āman dragged its wilting, oily body to the wall, turned around, and looked at Uta.

When she saw the fading gleam in the āman's eyes, the pangs of compassion suddenly welled up in her heart.

"Hiroshi, wait!" She had yelled, but she was too late. Kinjō's shovel, already in mid-swing, struck the āman. The blow smashed the āman's carapace, and a dark- green liquid gushed out. Even then, it was still alive. Uta realized that the creature's two eyes were still staring at her, and she was taken aback by a thought that suddenly flashed across her mind. This āman might be the reincarnation of Omito.

In a frenzy, Kinjō swung the shovel once more, delivering the finishing blow. (Medoruma, 2011:131-132)

In the turmoil to try and thwart the āman, it strikes Uta that the āman could be Omito's reincarnation. As mentioned above, the violence perpetrated by the àman represents the Battle of Okinawa, wherein Okinawa itself was the victim of the violence perpetrated by the mainland and the US military (Ōsawa, 2002:33). ${ }^{3}$ On the other hand, from Uta's perspective, the āman appears to be Omito, an association for which she must have a reason.

Retreating into the past, Uta recalls that she returned to the caves after Omito's death on the beach. Later, she learned that all the local men were taken by the Japanese soldiers, leaving behind only women and children. Uta, who was later released from the US military camp, returned to the beach, but could not find Omito's body and had no way of knowing where it was buried. In the present, only Omito's name is written on the ancestral memorial tablet. The fact that Uta could 
not find Omito's body indicates that the war was not over for Uta, and the fact that only she survived exacerbates her guilt and dilemma.

The following ideas convey the perception of death in Okinawa, particularly concerning the spirits of murdered people: the ancient ritual of washing the bones of deceased ancestors in Okinawa (Takahashi, 2015:46). After a person dies, their body is buried. However, if a descendant buries their ancestor's body without the ritual of washing the bones, it is believed that the ancestor's ghost can bring disaster to their descendants. Therefore, by washing the bones and purifying the soul of the deceased, the descendants are protected by the deceased who becomes an ancestral spirit that brings prosperity and fertility. In addition, it is also believed that people can become evil spirits depending on the nature of their death. For example, if a person dies in an accident, they will remain in that location because of their obsession with the world. It is believed that if someone is killed by another person, the spirit of the deceased can bring disaster to a living human, such as by haunting the killer.

Considering this custom of washing the bones, the spirit of Omito-who was killed by a Japanese soldier and hence not officially buried-would not have healed. Moreover, she had left behind her son, who was less than a year old. It is only natural that Omito's spirit would be transferred to the āman and attach itself to her son, Kōtarō. Uta thinks that caring for Kōtarō would relieve her of remorse and give her the opportunity to atone for her sins. However, it is more rewarding for Uta to see Kōtarō's growth. She thinks the āman might be Omito because she reasons that Omito has come to take away Kōtarō, who had been her life's purpose. Uta's perception of the āman as a reincarnation of Omito represents the indelible guilt she feels for abandoning Omito on the beach that fateful night.

By contrast, the āman has not invaded Kōtarō's body because of Uta's remorse. According to Susan Bouterey (2011:178179), Kōtarō's revival of his parents' traumatic memories is an image he has to erode from the inside, and the āman represents the violent part of the traumatic memory. It is an important point, and based on this, it is necessary to analyze Kōtarō's characteristics in more detail. Kōtarō is a child who often released his spirit, not just on this occasion, but from an early age. Kōtarō's wandering spirit represents his longing for his mother. This work depicts Kōtarō's emotions toward his mother, and the loss of his mother allows the āman to invade his body. This time, Kōtarō looks beyond the sea and does not try to go home.

The people of Okinawa believe that, after death, a person travels to the world beyond the sea. Kōtarō stares at the sea because of his longing for his mother, which summons her spirit, and he enters the world beyond the sea, where he believes she lives. The āman represents the transfer of his mother's spirit, which is summoned by Kōtarō's loneliness. Kōtarō experiences this loneliness because his parents were taken from him at an early age by the war.

In this work, the āman represents various metaphors. It symbolizes Okinawa, which was sacrificed by the mainland; it expresses indignation at the current situation; and it represents the mutual thoughts of Omito and Kōtarō. This reveals Uta's guilt as the sole survivor of the war.

\section{Personal Memory and Decentralization of History}

This section will examine how this short story depicts the decentralization of history by discussing individual memories that cannot be expressed in words, rather than the memories shared by the community. 
Uta is a woman who inherits the traditions of Okinawa. She is the shamanistic yuta, who brings spirits back into people's bodies when any villager loses their spirit. Owing to her ability, she can see the spirit of Kōtarō, who is sitting on the beach, outside his body. She understands Kōtarō's feelings toward his mother through her visual hallucinations. Besides Kōtarō's spirit, Uta also remembers two pasts. The first is a peaceful pre-war Okinawa, and the second is wartime Okinawa, where Uta's husband and Kōtarō's parents were killed by Japanese soldiers.

In her youth, she and the other young people gathered on the beach in the evenings and stayed up late moon gazing, drinking liquor, and singing to the accompaniment of the sanshin. They would sing songs to each other while everyone listened closely, passing on the best lyrics. Those who sang with feelings and sentiments were swooned over by everyone. It was during the many evenings spent in this fashion that she and Seiei had become acquainted. It was also the way Kōtarō's parents, Omito and Yūkichi, had first fallen in love. (Medoruma, 2011:122)

Back in the cave, everyone was starving: being without food was particularly difficult for the elderly and children, who were growing weaker by the day. Even though Uta felt she ought to help Omito dig up the eggs, she could not muster up the courage to leave her hiding place. She fretted as she watched, when suddenly a dry noise, like the crackling of bamboo in fire, reverberated across the beach and Omito toppled over sideways. Instinctively, Uta pressed her body and face deeper into the sand. Anticipating that machine-gun fire would begin at any moment, she silently uttered Seiei's name and prayed to the gods of the utaki. When the sound of the single rifle shot faded, she could again hear the waves and the rustling leaves. Uta raised her head and looked toward her friend. Omito remained completely intact. She had fallen on her side and her hand at the opening of the bag; Uta could see the bottom of her two tiny feet. Only her disheveled hair moved, blowing in the wind. (Medoruma, 2011:127)

The contrast between these two scenes highlights that the war completely changed the lives of the Okinawans. Moreover, through the case of the āman, the shadow of that war continues to affect the present. At the end of this work, it is said that Uta's prayer to the sea goes unanswered. This implies that the scars of the Battle of Okinawa have not disappeared (Saito, 2009:147). ${ }^{4}$ In contrast, the case of the āman also shows that the memories the community should share are divided.

"In any case, what I'm most concerned about is how this matter might affect the hotel construction plans by the company from mainland Japan," Shinzato said. Uta was shocked. This was rather different from what he had told her earlier. "After all, we're dealing with Yamato people, from mainland Japan, you know. And if they hear rumors about an āman entering someone's body, this will really alarm them! It might even spook them into canceling the plans for the hotel. With other areas in Okinawa trying to attract hotel construction and investment, if the word gets out about Kōtarō, then rumors will start spreading about our village. People will get the impression that strange things will crawl into your body if you stay here overnight. As you all know, Yamato people get nervous about things like this, not to mention that most of them are prejudiced against Okinawa. As you see, our bid for the hotel that we worked so hard for could be ruined." (Medoruma, 2011:120)

The above extract depicts the Okinawans who have forgotten the history of war and are collaborating with and supporting the mainland policy of turning Okinawa into a resort (Koshikawa, 1999:302). Only Uta refuses to connect with the mainland and becomes trapped in the past through her vision of another world. In other words, she is isolated and at odds with the members of the community. This work also depicts the division of villagers in their remembrance of the history of the Okinawa community. 
As such, the case of the āman is an illustration of various facts. First, there is a deep divide in the relationship between the mainland and the Okinawans, that is, between those who stubbornly reject the mainland policy and those who accept it. In other words, the divide exists between those who remember history and those who do not. In the above extract, it is confirmed that the people of mainland Japan are prejudiced against the people of Okinawa. Their misconceptions and biases finally drive Kōtarō to his death.

In addition, there was another thing to worry about. A little past noon the day before, two young men with cameras were seen loitering around the village. One of them was a Yamato mainlander, while the other was supposedly from Naha. When the two visited Ward Chief Shinzato, they initially took photographs of each village's historical ruins and local events for a news story. By the end of the conversation, however, Shinzato could tell that they were really after information about Kōtarō and his condition. (Medoruma, 2011:123)

From the standpoint of mainland Japan, Okinawa is just another place, and its people are treated as second-class citizens. This can be observed from the fact that this story was written in a mixed style that blends the languages of both Okinawa and mainland Japan. Expressing the feelings of people who have been excluded from the history of the mainland, this work depicts a Japanese soldier killing an Okinawan-who fought just like any other Japanese- during the Battle of Okinawa. History recorded on the mainland provides stark testimony about similar events in the surrounding areas. Therefore, there is no room for Okinawa's history to be realistically depicted in the history recorded on mainland Japan.

On the other hand, Tomoyuki Suzuki (2013:99) points out that the history of the Battle of Okinawa has been told in a different form every time an incident has emerged that led to Okinawa questioning its identity in relation to the mainland. For example, according to an article by Ōshiro Masayasu (1985:98-104), the war records of the Battle of Okinawa were edited and published by Okinawans after the 1950s, but the realistic depictions of these works weakened from the end of the 1950s into the 1960s. This weakening was precipitated by the tendency during this period to emphasize the dedicated cooperation of the inhabitants with the US military, in connection with the "movement to apply the Assistance Law." 5

However, from around 1970, when Okinawa's reversion to Japan was confirmed, facts such as the massacre of the residents by the Japanese army, were highlighted. Therefore, the discourse changes according to the convenience of the community and cannot accurately convey the wounds inflicted by the Battle of Okinawa on its people. In contrast, personal memories that are not easily recounted reflect the trauma of the Battle of Okinawa more clearly. In this story, Uta could not help Omito and feels guilty for being the lone survivor from her community. This is a miserable personal memory that cannot be narrated. The memories of the characters have been vividly described in this work: a bright moon, a sea turtle spawning, an āman, and Kōtarō's spirit are all visual elements that act as mediators of the past, sharpening the image of war. The memories of the war, remembered peacefully in everyday life, highlight the gravity of the trauma of those who experienced it. Therefore, the memory of the Battle of Okinawa, depicted through colorful nature, becomes even more realistic. Writing personal memories that cannot be easily articulated, provides readers with a glimpse of the struggle between life and death, along with the terrible violence of war, elements which are often excluded from sanitized mainstream narratives recounting the war.

Using such an approach to describe the memories of individuals who experienced war in Okinawa decentralizes history in two respects. One relativizes the mainland's historical narrative that Japanese soldiers did not kill the Okinawans in 
the Battle of Okinawa. The other creates a distance from the records of the battle, as the Okinawans have also changed historical narratives, though in a different way in relation to the mainland (Suzuki, 2013:102). As a result, the history of the battle, as narrated in mainland Japan and in Okinawa, is decentralized.

\section{Conclusion}

Medoruma Shun describes the history of Okinawa based on its landscape and living things. The wounds of people who experienced the Battle of Okinawa are projected and visualized through the Okinawan traditions. The readers are made to feel that they are actually watching an āman crawl into a person's mouth, the moonlight reflecting on the surface of the sea, and a sea turtle digging a hole to spawn. Consequently, the memory of the war comes to the fore. This style of writing can also be observed in the author's previous work 'Suiteki' ('Droplets,' 1997). In that story, one day, the phantom soldiers who died in the Battle of Okinawa appear to Tokumasa. These soldiers drink the water that drips from Tokumasa's big toe, which has been torn like a spout. These soldiers had been left behind in the trench, and Tokumasa harbors feelings of guilt about his own survival (Medoruma, 1997:423-450). Personal memories that cannot be shared in words can only be expressed through imagery, and the memories visualized in this manner allow the reader to experience the cruelty of war vicariously. This seems to be the true essence of Medoruma Shun's corpus.

In a paper about 'Mabuigumi,' Kojima Yōsuke (2009:90) has observed that the development of Okinawa by the mainland was "Japanese-like," as symbolized by the two photographers from the mainland and Naha, as well as by the construction of a hotel in Okinawa. In addition, he has asserted that the mainland imposes its framework on and exerts control over Okinawa's development: for instance, the construction of hotels to turn Okinawa into a resort for mainlanders. Susan Bouterey (2011:183-207) has further observed that Uta was unsuccessful in performing her functions as a priestess because of the destruction of Okinawa's indigenous culture by the mainland, which is symbolized by "radio calisthenics" in the text. Radio calisthenics has been practiced nationwide in Japan for the health of the people in modern times and represents the culture of the mainland as opposed to that of Okinawa. Based on these ideas, this article posits that the descendants of the victims/survivors of the Battle of Okinawa bear the burden of the war and memories of their ancestors. These memories continue to traumatize the post-war generation. 'Mabuigumi' relativizes and decentralizes the official historical narratives of the mainland and Okinawa by focusing on personal memories of the war. This article emphasizes the importance of personal memories of war that cannot be narrated, as well as the memories evoked through landscapes and living things, considering that these elements also evade narration.

Medoruma Shun shows that the true horror of war is an individual's experience of war, which cannot actually be described. The guilt of surviving a war when the people around an individual have died, often prevents survivors from narrating their experiences. Through the main protagonist, Medoruma Shun's work focuses on aspects that cannot be articulated without feeling guilt. This method reveals history that cannot be narrated from the perspective of mainland Japan and distances it from discourse concerning the Battle of Okinawa, which has played a pivotal role in shaping Okinawa's relationship with the mainland. This destroys the privileged discourse of the relationship between the mainland and Okinawa. In other words, it highlights that writing about previously unspeakable personal experiences of war is a way of attacking the dominant discourse and an attempt to overshadow the same.

Many Okinawans had no intention of fighting the US military and were trying to avoid the war (Onishi, 2019:44-47). Yet, they fought at the behest of the mainland. This relationship between the mainland and Okinawa still exists. Following the 
end of the war in 1945, the US military base was relocated to Okinawa, and now, about $70.27 \%$ of the total area of US military facilities in Japan are concentrated in Okinawa. In addition, Okinawa has become a resort where people from the mainland come to relax. 'Mabuigumi' depicts the relationship between the mainland and Okinawa, focusing on those who experienced the Battle of Okinawa and their descendants, but it also highlights the current state of the island.

\section{Acknowledgements}

This work was supported by the Ministry of Education of the Republic of Korea and the National Research Foundation of Korea (NRF 2019S1A5A2A01048354).

\section{Endnotes}

1. Kyle Ikeda points out the first-generation war memories and the multiplicity embedded in the landscape.

2. Kojima Yōsuke indicates that Uta's perception of immutable nature leads to her personal salvation. In this article, I have analyzed this work from the standpoint that the characters overlap the past and the present because of the cycles of nature.

3. Ōsawa Masachi suggested that the āman, which did not have Kōtarō's body, symbolizes the US military forces stationed in Okinawa.

4. Regarding this ending, Saito Hiroshi identified that all the significances of everyday life that Uta accumulated after the war seem to be reduced to ashes.

5. Its official name is the "Law for Relief of War Victims and Survivors." The purpose of this law is to provide support based on the spirit of state compensation for public affairs, injured or sick persons, and bereaved family members of those who died in the war. It was enacted in 1952. However, during the time, no relief money was paid to Okinawa, which continued to be under US military administration. The law was applied to Okinawa in 1953 under pressure from the movement to apply the Assistance Law (April 30, 1952, Law No. 127). Ministry of Internal Affairs and Communications, https://www.soumu.go.jp/english/. The original text is in Japanese.

\section{References}

Bouterey, S., 2011. Mabuigumi ron (Theory about Mabuigumi), in: Medoruma Shun no sekai (Okinawa): Rekish • Kioku • Monogatari (The world of Medoruma Shun (Okinawa): History • Memori • Monogatari). Kage Shobō, Tokyo, pp. 163-215.

Ikeda, K., 2012. Geographically-proximate postmemory: Sites of war and the enabling of vicarious narration in Medoruma Shun's fiction. Int. J. Okinawan Stud. 3: 37-60.

Kojima, Y., 2009. Medoruma Shun Mabuigumi: lyasarenu yamai (Medoruma Shun's Mabuigumi: Unhealed illness). Chibadaigaku jinbunshakai kagaku kenkhuka kenkhu project hōkokusho. Chiba University Graduate School of Humanities and Social Sciences Research Project Reports. 184: 85-95.

Koshikawa, Y., 1999. Tatta hitori no kakuto (Only one fight), Shinchō (New Tide). 98: 302-303.

Medoruma, S., 1997. Suiteki (Droplets), Bungeishunju. 75:423-450.

Medoruma, S., 2011. Mabuigumi. Ikeda, K. (Trans.). Mānoa. 23: 112-134. 
Ministry of Internal Affairs and Communications, n.d. https://www.soumu.go.jp/english/.

Onishi, Y., 2019. Shiru koto to kataru koto no rinri: Medoruma Shun no bungaku wo kangaeru tameni (Ethics of knowing and talking: To think about Medoruma Shun's literature). Mie daigaku nihon gogaku bungaku (Mie University Japanese Language Literature). 30: 39-49.

Ōsawa, M., 2002. Huhentekina kōkyōsei wa ikani shite kanō ka (How universal commonality is possible?), in: Kaneko, M., Ōsawa, M. (Eds.), Kyodō shuzai: Mitakunai shisōteki genjitsu wo miru (Joint coverage: Watching the ideological reality that we don't want watch). Iwanami Shoten, Tokyo, pp. 23-41.

Ōshiro, M., 1985. Naze Okinawa wa kodawari tsuzukerunoka (Why Okinawa keeps sticking with it). Sekai (World). 475: 98-104.

Saito, H., 2009. Medoruma Shun: Kaminchu no todokanai inori (Prayer that is out of the reach of the goddess), Kokubungaku: Kaishaku to kanshō (National Literature: Interpretation and Appreciation). 74: 142-148.

Suzuki, T., 2013. Gūwateki akui: Suiteki Mabuigumi ni okeru Okinawasen no kioku no keishō (Allegorical malice: An image of the memory of the battle of Okinawa in 'A Drop of Water' and 'Spirit Stuffing'), in: Me no oku ni tsukitaterareta kotoba no mori: Medoruma Shun no bungaku to Okinawasen no kioku (A harpoon of words thrust into the back of the eye: Memories of Medoruma Shun's literature and the battle of Okinawa). Shōbunsha, Tokyo, pp. 53-116.

Takahashi, T., 2015. Tamashii no kan'nen: Ryūkyū no minkan shinkō (Idea of the soul: Ryūkyū folk beliefs). Kodomo kyōiku hōsen daigaku kiyō (Bulletin of Hosen College of Childhood Education). 6: 43-49. 